\title{
Liana species composition differs, in spite of trait similarities, in two adjacent forest types in Central Brazil
}

\author{
Ana Carolina Souza Brito ${ }^{1}$, Alexandre Ferraro², Vivian Almeida Assunção ${ }^{3}$, Robyn J. Burnham ${ }^{4}$
} \& Ângela Lúcia Bagnatori Sartori ${ }^{5 *}$

1. Department of Plant Biology, Institute of Biology, State University of Campinas, CEP 13083-970, Campinas, SP, Brazil; ana_brito_1987@hotmail.com

2. Laboratório de Anatomia Vegetal, Departamento de Ciências Biológicas, Escola Superior Agrícola "Luiz de Queiroz". Av. Pádua Dias, 11, CEP 13418900, Piracicaba, São Paulo, Brasil; alxferraro@gmail.com

3. Rio de Janeiro Botanical Garden Research Institute (JBRJ), Botanical Sistematics Unity, Rua Pacheco Leão 915 / sala 213, Jardim Botânico, 22460-030, Rio de Janeiro, RJ, Brazil; vivian.bios@gmail.com

4. Department of Ecology and Evolutionary Biology, University of Michigan, 1109 Geddes Avenue, Ann Arbor, MI 48109-1079 U.S.A.; rburnham@umich.edu

5. Program in Vegetal Biology, Federal University of Mato Grosso do Sul, Caixa Postal 549, 79070-900, Campo Grande, MS, Brazil; albsartori@gmail.com

* Correspondence

Received 06-IX-2016. C Corrected 08-V-2017. Accepted 06-VI-2017.

\begin{abstract}
In the Parana basin, the Serra de Maracaju juxtaposes the Seasonal Dry Forest and the cerradão (a phytophysiognomy of Cerrado), two distinct vegetation types that differ in canopy height, tree density, and composition of the understory. In the same way, these differences may be reflected in the composition of climbing plant species found in these two forest types. Thus, in this study we compared the climbing species in two forest fragments of Serra de Maracaju to understand: (1) Are species richness and floristic composition of climbing plants similar in cerradão and seasonal deciduous forest?, (2) What degree of floristic compositional difference exists between the two vegetation types?, (3) Do the two vegetation types differ significantly in climbing mechanisms, life forms, and dispersal syndromes represented among climbing species? For this, we established and sampled four plots per forest type over 24 months. Species were identified and each one classified, based on three discrete traits. Proportional differences were analyzed using chi-square tests. Our results showed that species richness and floristic composition of climbing plants in the cerradão and the seasonal deciduous forest were not similar. Climber species richness in cerradão was 37 while in the seasonal deciduous forest it was 31; they share only 13 species. Four families, Dioscoreaceae, Fabaceae, Malpighiaceae, and Sapindaceae, included over $60 \%$ of the climbing species. The morphological traits most common in both forest types were herbaceous life form, apical twining mechanism, and wind dispersal. Dioscoreaceae was found to be the dominant family, but is the first time to be reported for this condition in Brazil. Bignoniaceae and Passifloraceae ocurred only in the cerradão, and Asteraceae and Combretaceae in the seasonal deciduous forest; some species were found exclusively in a type of forest. Floristic composition of the cerradão and seasonal deciduous forest fragments were substantially different, in spite of physical proximity. However, their climbing species are not statistically distinct in morphological characteristics, possibly due to uniform climatic conditions and the similarity of species because of a shared ancestry (similar families). Rev. Biol. Trop. 65 (3): 1215-1225. Epub 2017 September 01.
\end{abstract}

Key words: climbing mechanism, dispersion, life form, cerradão, Dioscoreaceae.

Tropical climates support climbing floras with high species richness, morphological diversity, and phylogenetic diversity. Climber species play essential roles in tropical plant communities, contributing with significant richness to tropical forests (Hergarty \& Caballé, 1991; Engel, Fonseca, \& Oliveira, 1998), and occurring in both evergreen and seasonal forests. Collectively, climbers show tolerance to large ranges of latitude, altitude, climate, 
and soil types (Gentry, 1991). At least 133 plant families include the climbing habit, which evolved independently several times; indeed almost $40 \%$ of vascular plant families in Brazil include climbers (Schenck, 1892; Richards, 1952; Gentry, 1991; Araújo \& Alves, 2010). Climbers vary from absent or scarce in grasslands, to dominant in "Mata de Cipó" (liana forest), a type of ombrophilous forest in the Southern Amazon basin (Engel et al., 1998; IBGE, 2012). In Central Brazil, climbers are diverse and widely distributed in Cerrado (or Savanna) vegetation (Filgueiras, 2002) and in other seasonal forests (Hora \& Soares, 2002; Rezende \& Ranga, 2005).

While climbing species may tolerate different soil and climatic conditions, local biotic and abiotic factors may determine the presence and abundance of individual species. These factors include host plant availability, canopy density, and temperature and rainfall seasonality (Putz, 1984; Gentry, 1991). Similarly, morphological variation in life form, climbing mechanism, and dispersal syndrome may be associated with climber distribution: for example herbaceous species are more prevalent in open vegetation while woody species are more common in mature forest. The apical twining mechanism for ascent is the most common mechanism in most studied habitats, and because it is effective on host plants of small diameter, many species are apical twiners where richness is high (Putz \& Holbrook, 1991). Wind dispersal (anemochory) is often cited as the most common dispersal strategy for climbers, and increases relative to animal dispersal, especially in dry forests (Gentry, 1991).

Close floristic relationships have been proposed for Cerrado vegetation and fragments of seasonal forest that resulted from climatic and edaphic changes at the end of the Quaternary (Pinheiro \& Monteiro, 2010). Cerrado encompasses several vegetation sub-types (Ribeiro \& Walter, 1998), ranging from forest (riparian forest and cerradão) to savannas (cerrado sensu stricto, savannah park, palmeiral, vereda), to countryside (disturbed fields, rocky fields, grasslands). Seasonal forests may link savanna to other vegetation types and promote species compositional similarities (OliveiraFilho \& Ratter, 2002; Pinheiro \& Monteiro, 2010). Seasonal forests are distinct from cerradão in growing on deeper and more fertile soils (Oliveira-Filho \& Ratter, 2002; Salis et al., 2004).

This distinction between seasonal forest and cerradão is seen in central Brazil in the Serra de Maracaju, a series of escarpments on the basalt plateau in the Parana basin. The vegetation contact extends from South-Central Brazil to Uruguay, and from Mato Grosso do Sul to the adjacent states of Goias and Mato Grosso (Martins, 2003). The Southern part of the mountain range is rugged with steep hills, harboring several phytophysiognomies of varying floristic composition, which may allow interconnections between seasonal forests and other vegetation types. Previous research in the region (Ramos \& Sartori, 2013; Assunção, Casagrande, \& Sartori, 2014) did not include climbing species. High rates of deforestation in the mountain range contribute to a lack of information on the flora and its biogeographical affinities. Knowledge of the species that are restricted to specific environmental conditions (e.g., hills with rocky outcrops or valleys with deeper soils) would provide a better picture of the regional conservation value, the included phytophysiognomies, and their species diversity.

For this study, we predicted that the climber composition in two phytophysiognomies of the Serra de Maracaju would be different, based on differences in the structure of the host vegetation that provides support for climbing plants. This prediction derives from climbing plant data from other fragmented forests, such as seasonal and riparian forests (Rezende \& Ranga, 2005; Santos, Kinoshita, \& Rezende, 2009; Vargas, Araújo, Schiavini, Rosa, \& Hattori, 2013). We aimed to answer these questions: (1) What is the species richness and floristic composition of climbing plants in cerradão versus seasonal deciduous forest?, (2) What degree of floristic compositional difference exists between the two vegetation types?, 
and (3) Do the two phytophysiognomies differ significantly in climbing mechanisms, life forms, and dispersal syndromes of climbers?

\section{MATERIAL AND METHODS}

Study area: Located in the Parana basin plateau, the Serra de Maracaju divides the state of Mato Grosso do Sul between the drainages of the Paraguay River to the West, and the Paraná River to the East (Martins, 2003). The Furnas do Dionísio is vegetated by Cerrado, with interspersed fragments of seasonal forest (RADAMBRASIL, 1982; IBGE, 2012). The Seasonal Deciduous Forest (SDF) consists of dense, 12 to $15 \mathrm{~m}$ trees forming a closed canopy whose understory includes abundant shrubs and climbers, with grasses and subshrubs on rocky outcrops. The cerradão (a subset of Cerrado) is composed of sparse to dense, twisted trees (up to $4 \mathrm{~m}$ tall), with an understory predominantly composed of shrubs, sub-shrubs, and grasses in which climbers are less commonly encountered. The climate of the region is an "Aw" type (Köeppen, 1948), with both rainy (October to March) and dry seasons (April to September). The average annual temperature is $23{ }^{\circ} \mathrm{C}$, average annual rainfall is 1 $500 \mathrm{~mm}$ (MMA, 2007), and mean altitude is 500 m.a.s.l. SDF and cerradão are found on hillsides of the Serra $\left(20^{\circ} 05^{\prime} 00^{\prime \prime}-20^{\circ} 30^{\prime} 00^{\prime \prime} \mathrm{S}\right.$ and $54^{\circ} 45^{\prime} 00^{\prime \prime}-54^{\circ} 15^{\prime} 00^{\prime} \mathrm{W}$ ).

We delimited eight $25 \times 50 \mathrm{~m}$ plots on the slopes of the Serra de Maracaju, over an area of 34 ha, with four plots in each of the two forest types (SDF and cerradão), for a total sample area of 1 ha. Plots in forest fragments were selected randomly in each phyto-physiognomy, therefore spacing between plots was not equal. Plots 1-4 were in seasonal deciduous forest and 5-8 were in cerradão. All plants rooted in the soil and supported by another plant were considered climbers (Gentry, 1991). All plants were collected in fertile condition to enable species identification, with collections made monthly from December 2009 to November 2011 (24 months). A plant species was collected from each plot where it occurred. Climbing stems of all diameters were considered so as to include both herbaceous and woody life forms. The family level classification followed the system of APG III (2009), and species determinations were made using taxonomic literature and advice of family and generic-level specialists. Identified materials were deposited at CGMS herbarium, Federal University of Mato Grosso do Sul, Brazil (UFMS).

\section{Species characterization and statistical} analysis: We used the four-part climbing mechanism classification of Hergarty and Caballé (1991): 1) Apical twining: apically winding stems that continuously wrap around the host; 2) Tendrilling: bearing tendrils, a determinate coiling organ derived from leaflets, stipules, petioles, axillary buds, or inflorescence axes; 3) Scandent: bearing hooked spines or thorns only; or 4) Radicant: bearing roots adapted to adhere to the host. Life form was classified following Gentry (1991), with herbaceous climbers bearing thin, flexible stems, versus woody climbers bearing thick, relatively rigid stems. Diaspores were classified according to Van der Pijl (1982) as anemochorous (winged or plumed diaspores), zoochorous (scattered by animals), or autochorous (dispersed by explosion or gravity).

Non-Metric Multidimensional Scaling (NMDS) based on the Jaccard Similarity Index was used to test community similarity of species presence and absence for each plot sampled. A non-parametric analysis of similarity (ANOSIM, Clarke, 1993) with 10000 permutations was employed to test for significant differences among groupings. Analysis of the differences between the proportions of climbing mechanisms, life forms, and dispersal syndromes were performed using chi-square tests (Zar, 1984).

\section{RESULTS}

Richness and floristic composition: Neither species richness nor floristic composition of climbing plants was similar between cerradão and Seasonal Deciduous Forest (SDF) (Fig. 1; 


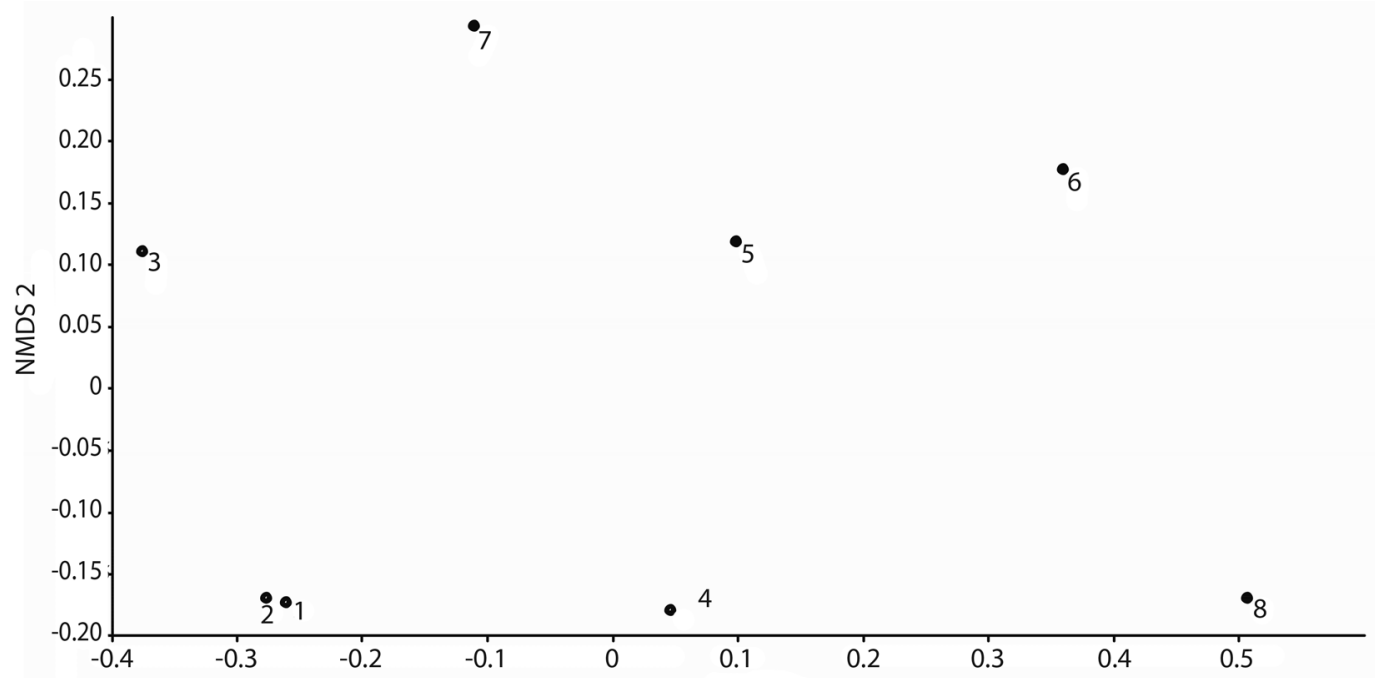

Fig. 1. Similarity among climber using non-metric multidimensional scaling (NMDS) ordination in plots in cerradão and Seasonal Deciduous Forest in the Serra de Maracaju, Mato Grosso do Sul, Brazil. Plots 1-4: Seasonal Deciduous Forest; plots 5-8: cerradão (number of dimensions $\mathrm{k}=2$ ).

NMDS: $\mathrm{R}^{2}=0.35$, stress $=0.3$. ANOSIM: $\mathrm{R}^{2}=$ $0.48, \mathrm{p}=0.03)$. Fifty-five species, belonging to 26 genera and 14 families were found among the eight $25 \times 50 \mathrm{~m}$ plots sampled. Only 13 species were shared between both vegetation types. The most speciose families were Dioscoreaceae (ten species), followed by Fabaceae (eight), Malpighiaceae (eight), Sapindaceae (seven) and Convolvulaceae (six). In cerradão alone, 31 species (20 genera, 12 families) were found; the most speciose families were Sapindaceae and Fabaceae (five species each), followed by Dioscoreaceae and Malpighiaceae (four each). In SDF, 37 species (19 genera, 12 families) were found; Dioscoreaceae was the most diverse family (six species), followed by Sapindaceae (five), Malpighiaceae and Convolvulaceae (four each). The most species-rich genera overall were Dioscorea (ten species), Ipomoea, Heteropterys, and Serjania (five each); Dioscorea and Serjania were present in both vegetation types, while Heteropterys and Ipomoea were present only in SDF (Table 1).

Individual plots included from 9 to 18 fertile species during the 24 months of collection. SDF plots included 13 to 18 species each, while cerradão had 9 to 14 species per plot. Only one species, Dioscorea sinuata, was found fertile in all four SDF plots, while Serjania caracasana was the only species occurring as a fertile specimen in three cerradão plots. The average number of species occurrences per forest type (fertile specimens) was only 1.07 for SDF and 0.84 for cerradão. Because our survey included only fertile specimens, the total number of species that are shared between the forest types is not known.

Morphological characters: The most commonly encountered individual traits for climber species in the study area were herbaceous habit, apically twining climbing mechanism, and anemochorous dispersal (Fig. 2). This combination of traits was present in 11 species across the two vegetation types. However, the most common combination of character states among all species was herbaceous habit, apical twining, and autochorous dispersal (14 species). No significant difference was found among the distribution of character states from cerradão versus SDF (life form: $\mathrm{x}^{2}=1.195, \mathrm{p}=$ 0.32 ; climbing mechanism: $x^{2}=1.016, p=0.60$; dispersal syndrome: $\mathrm{x}^{2}=3.362, \mathrm{p}=0.19$ ). 
TABLE 1

Climber species and morphology in two phytophysiognomies in the Serra de Maracaju, Mato Grosso do Sul state, Brazil

\begin{tabular}{|c|c|c|c|c|c|c|c|}
\hline \multirow{2}{*}{ Family } & \multirow{2}{*}{ Climber Species } & \multicolumn{2}{|c|}{ Phytophysiognomies } & \multirow{2}{*}{$\begin{array}{l}\text { Life } \\
\text { Form }\end{array}$} & \multirow{2}{*}{$\begin{array}{l}\text { Climbing } \\
\text { Mechanism }\end{array}$} & \multirow{2}{*}{$\begin{array}{l}\text { Dispersal } \\
\text { syndrome }\end{array}$} & \multirow{2}{*}{$\begin{array}{l}\text { Voucher } \\
\text { CGMS }\end{array}$} \\
\hline & & CE & SDF & & & & \\
\hline \multirow[t]{2}{*}{ APOCYNACEAE } & Mesechites mansoanus (A.DC.) Woodson & & $\mathrm{X}$ & $\mathrm{H}$ & $A T$ & ANE & 41360 \\
\hline & $\begin{array}{l}\text { Tassadia berteroana (Spreng.) } \\
\text { W.D. Stevens } \\
\end{array}$ & $\mathrm{X}$ & $\mathrm{X}$ & $\mathrm{H}$ & $A T$ & ANE & 41361 \\
\hline ASTERACEAE & Dasyphyllum vagans (Gardner) Cabrera & & $X$ & W & $S C$ & ANE & 41419 \\
\hline BIGNONIACEAE & Fridericia pubescens (L.) L.G. Lohmann & $\mathrm{X}$ & & $\mathrm{W}$ & $T E$ & ANE & 41364 \\
\hline COMBRETACEAE & Combretum rotundifolium Rich. & & $\mathrm{X}$ & $\mathrm{W}$ & $A T$ & ANE & 41365 \\
\hline \multirow[t]{6}{*}{ CONVOLVULACEAE } & Ipomoea indivisa (Vell.) Hallier f. & $X$ & $\mathrm{X}$ & $\mathrm{H}$ & $A T$ & AUT & 41367 \\
\hline & Ipomoea ramosissima (Poir.) Choisy & $\mathrm{X}$ & & $\mathrm{H}$ & $A T$ & AUT & 41371 \\
\hline & Ipomoea nil (L.) Roth. & & $X$ & $\mathrm{H}$ & $A T$ & AUT & 41369 \\
\hline & Ipomoea cynanchifolia Meisn. & & $\mathrm{X}$ & $\mathrm{H}$ & $A T$ & AUT & 41370 \\
\hline & Ipomoea $\mathrm{cf}$. rubens Choisy & & $\mathrm{X}$ & $\mathrm{H}$ & $A T$ & AUT & 41372 \\
\hline & Jacquemontia velutina Choisy & $\mathrm{X}$ & & $\mathrm{H}$ & $A T$ & ANE & 41363 \\
\hline \multirow[t]{10}{*}{ DIOSCOREACEAE } & Dioscorea cf. sinuata Vell. & & $\mathrm{X}$ & $\mathrm{H}$ & $A T$ & ANE & 41374 \\
\hline & Dioscorea amaranthoides C. Presl & & $\mathrm{X}$ & $\mathrm{H}$ & $A T$ & ANE & 41373 \\
\hline & Dioscorea aesculifolia R. Kunth & & $\mathrm{X}$ & $\mathrm{H}$ & $A T$ & ANE & 41379 \\
\hline & Dioscorea cf. altíssima Lam. & & $\mathrm{X}$ & W & $A T$ & ANE & 41408 \\
\hline & Dioscorea demourae Uline ex. R. Kunth & $\mathrm{X}$ & & $\mathrm{H}$ & $A T$ & ANE & 41380 \\
\hline & Dioscorea glandulosa (Griseb.) Kunth & $\mathrm{X}$ & & $\mathrm{H}$ & $A T$ & ANE & 41381 \\
\hline & Dioscorea grandiflora Mart. ex Griseb. & $\mathrm{X}$ & & $\mathrm{H}$ & $A T$ & ANE & 41382 \\
\hline & Dioscorea orthogoneura Uline ex. Hochr. & & $\mathrm{X}$ & $\mathrm{H}$ & $A T$ & ANE & 41383 \\
\hline & Dioscorea ovata Vell. & & $\mathrm{X}$ & $\mathrm{H}$ & $A T$ & ANE & 41384 \\
\hline & Dioscorea sincorensis R. Kunth & $\mathrm{X}$ & & W & $A T$ & ANE & 41407 \\
\hline \multirow[t]{3}{*}{ EUPHORBIACEAE } & Manihot anomala Pohl & & $\mathrm{X}$ & W & $\mathrm{SC}$ & AUT & 41385 \\
\hline & Manihot tripartita (Spreng.) Müll. Arg. & $\mathrm{X}$ & $\mathrm{X}$ & W & $\mathrm{SC}$ & AUT & 41386 \\
\hline & Tragia hieronymi Pax \& K. Hoffm. & $\mathrm{X}$ & $\mathrm{X}$ & $\mathrm{H}$ & $A T$ & AUT & 41403 \\
\hline \multirow{8}{*}{$\begin{array}{l}\text { FABACEAE } \\
\text { (Papilionoideae) }\end{array}$} & Camptosema ellipticum (Desv.) Burkart & $\mathrm{X}$ & & $\mathrm{H}$ & $A T$ & AUT & 41387 \\
\hline & $\begin{array}{l}\text { Centrosema sagittatum (Humb. \& Bonpl. } \\
\text { ex Willd.) Brandegee }\end{array}$ & $X$ & $\mathrm{X}$ & $\mathrm{H}$ & $A T$ & AUT & 41389 \\
\hline & Galactia benthamiana Micheli & & $\mathrm{X}$ & W & $A T$ & AUT & 50235 \\
\hline & Galactia striata (Jacq.) Urb. & $\mathrm{X}$ & & $\mathrm{H}$ & $A T$ & AUT & 41391 \\
\hline & $\begin{array}{l}\text { Leptospron adenanthum (G. Mey.) } \\
\text { A. Delgado }\end{array}$ & & $\mathrm{X}$ & $\mathrm{H}$ & $A T$ & AUT & 41390 \\
\hline & Rhynchosia edulis Griseb. & & $\mathrm{X}$ & $\mathrm{H}$ & $A T$ & AUT & 41392 \\
\hline & $\begin{array}{l}\text { Ancistrotropis firmula (Mart. Ex Benth.) } \\
\text { A. Delgado }\end{array}$ & $\mathrm{X}$ & & $\mathrm{H}$ & $A T$ & AUT & 41393 \\
\hline & $\begin{array}{l}\text { Ancistrotropis peduncularis (Kunth) } \\
\text { A. Delgado }\end{array}$ & $\mathrm{X}$ & & $\mathrm{H}$ & $A T$ & AUT & 41394 \\
\hline \multirow[t]{8}{*}{ MALPIGHIACEAE } & $\begin{array}{l}\text { Banisteriopsis argyrophylla (A. Juss.) } \\
\text { B. Gates }\end{array}$ & & $\mathrm{X}$ & W & $A T$ & ANE & 41395 \\
\hline & Heteropterys cf. cochleosperma A. Juss. & $\mathrm{X}$ & $\mathrm{X}$ & W & $A T$ & ANE & 41397 \\
\hline & Heteropterys dumetorum (Griseb.) Nied. & & $\mathrm{X}$ & W & $A T$ & ANE & 41398 \\
\hline & Heteropterys cf. glandulosa A. Juss. & & $X$ & W & $A T$ & ANE & 41400 \\
\hline & $\begin{array}{l}\text { Heteropterys cf. intermedia (A. Juss.) } \\
\text { Griseb. }\end{array}$ & & $X$ & W & $A T$ & ANE & 41401 \\
\hline & Heteropterys tomentosa A. Juss. & $X$ & & W & $A T$ & ANE & 41402 \\
\hline & Janusia guaranitica (A. St.-Hil.) A. Juss. & $\mathrm{X}$ & & $\mathrm{H}$ & $\mathrm{SC}$ & ANE & 41396 \\
\hline & Mascagnia cordifolia (A. Juss.) Griseb. & $\mathrm{X}$ & $\mathrm{X}$ & W & $\mathrm{SC}$ & ANE & 50236 \\
\hline
\end{tabular}


TABLE 1 (Continued)

\begin{tabular}{|c|c|c|c|c|c|c|c|}
\hline \multirow{2}{*}{ Family } & \multirow{2}{*}{ Climber Species } & \multicolumn{2}{|c|}{ Phytophysiognomies } & \multirow{2}{*}{$\begin{array}{l}\text { Life } \\
\text { Form }\end{array}$} & \multirow{2}{*}{$\begin{array}{l}\text { Climbing } \\
\text { Mechanism }\end{array}$} & \multirow{2}{*}{$\begin{array}{l}\text { Dispersal } \\
\text { syndrome }\end{array}$} & \multirow{2}{*}{$\begin{array}{l}\text { Voucher } \\
\text { CGMS }\end{array}$} \\
\hline & & CE & SDF & & & & \\
\hline \multirow[t]{2}{*}{ PASSIFLORACEAE } & Passiflora pohlii Mast. & $\mathrm{X}$ & & $\mathrm{H}$ & $T E$ & ZOO & 41405 \\
\hline & Passiflora tricuspis Mast. & $\mathrm{X}$ & & $\mathrm{H}$ & $T E$ & $\mathrm{ZOO}$ & 41404 \\
\hline RUBIACEAE & Manettia cordifolia Mart. & $\mathrm{X}$ & $\mathrm{X}$ & $\mathrm{H}$ & $A T$ & AUT & 41406 \\
\hline \multirow[t]{8}{*}{ SAPINDACEAE } & Serjania hebecarpa Benth. & $\mathrm{X}$ & $\mathrm{X}$ & $\mathrm{W}$ & $T E$ & ANE & 41410 \\
\hline & Serjania marginata Casar. & & $\mathrm{X}$ & $\mathrm{H}$ & $T E$ & ANE & 41409 \\
\hline & Serjania caracasana (Jacq.) Willd. & $\mathrm{X}$ & $\mathrm{X}$ & W & $T E$ & ANE & 41411 \\
\hline & Serjania erecta Radlk. & & $\mathrm{X}$ & W & $T E$ & ANE & 41412 \\
\hline & Serjania perulacea Radlk. & $\mathrm{X}$ & $\mathrm{X}$ & W & $T E$ & ANE & 41413 \\
\hline & Serjania setigera Radlk. & & $\mathrm{X}$ & W & $T E$ & ANE & 41414 \\
\hline & Urvillea laevis Radlk. & $\mathrm{X}$ & & W & $T E$ & ANE & 41415 \\
\hline & Urvillea ulmacea Kunth & & $\mathrm{X}$ & W & $T E$ & ANE & 41416 \\
\hline \multirow[t]{2}{*}{ SMILACACEAE } & Smilax campestris Griseb. & $\mathrm{X}$ & & W & $T E$ & $\mathrm{ZOO}$ & 50237 \\
\hline & Smilax fluminensis Steud. & $\mathrm{X}$ & $\mathrm{X}$ & $\mathrm{H}$ & $T E$ & $\mathrm{ZOO}$ & 41417 \\
\hline \multirow[t]{2}{*}{ VITACEAE } & Cissus alata Jacq. & $\mathrm{X}$ & $\mathrm{X}$ & $\mathrm{H}$ & $T E$ & $\mathrm{ZOO}$ & 41420 \\
\hline & $\begin{array}{l}\text { Cissus verticillata (L.) Nicolson \& } \\
\text { C.E. Jarvis }\end{array}$ & $\mathrm{X}$ & & $\mathrm{H}$ & $T E$ & $\mathrm{ZOO}$ & 41421 \\
\hline
\end{tabular}

Phytophysiognomies: CE, Cerradão; SDF, Seasonal Deciduous Forest; Life Form: H, Herbaceous; W, Woody; Climbing Mechanism: AT, Apical Twining; TE, Tendrilling; SC, Scandent; Dispersal syndrome: ANE, Anemochory; AUT, Autochory; ZOO, Zoochory.

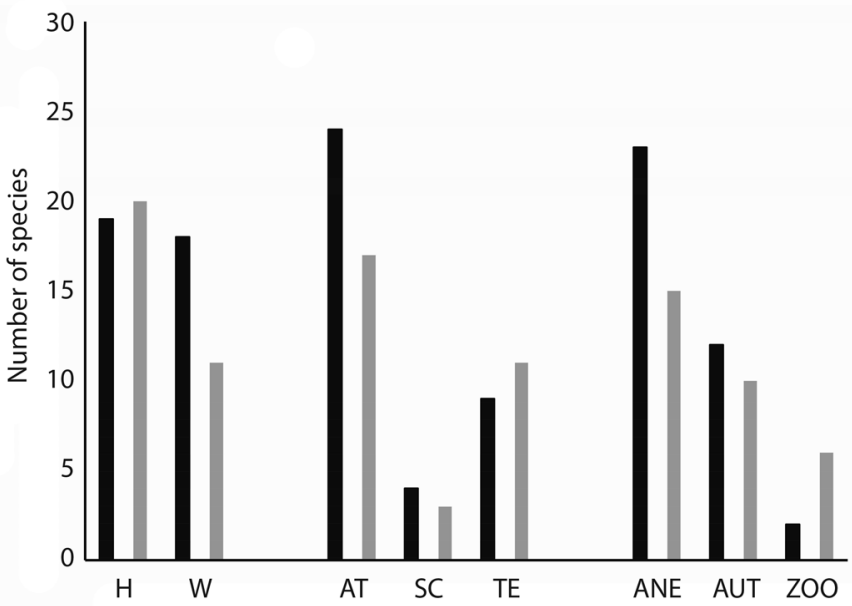

Fig. 2. Life form, twining mechanism and dispersal syndrome in cerradão (CE) and Seasonal Deciduous Forest (SDF) in the Serra de Maracaju, Mato Grosso do Sul, Brazil. Life Form: Herbaceous (H), Woody (W); Climbing Mechanism: Apical Twining (AT), Tendrilling (TE), Scandent (SC); Dispersal Syndrome: Anemochory (ANE), Autochory (AUT), Zoochory (ZOO). Seasonal Deciduous Forest (black bars) and cerradão (gray bars).

Life form: Our census included a total of $32(58.2 \%)$ herbaceous and $23(41.8 \%)$ woody climbing species. In cerradão, 20 species $(64.5 \%)$ were herbaceous and $11(35.5$ $\%)$ were woody. In SDF, 19 species $(51.4 \%)$ were herbaceous and 18 (48.6\%) were woody (Table 2, Fig. 2).

Climbing mechanism: We found $35(63.6$ $\%)$ apically twining species, 15 (27.3\%) tendrilling species, and five $(9.1 \%)$ scandent 
TABLE 2

Morphological characters of 55 climber species in cerradão and SDF (Seasonal Deciduous Forest) in the Serra de Maracaju, Mato Grosso do Sul state, Central Brazil

\begin{tabular}{lcccccccc} 
& \multicolumn{2}{c}{ Life forms } & \multicolumn{3}{c}{ Climbing mechanism } & \multicolumn{3}{c}{ Dispersal syndrome } \\
& Herbaceous & Woody & Apical Twining & Tendrilling & Scandent & Anemochoric & Autochoric & Zoochoric \\
Cerradão & $20(64.5 \%)$ & $11(35.5 \%)$ & $17(54.8 \%)$ & $11(35.5 \%)$ & $3(9.7 \%)$ & $15(48.4 \%)$ & $10(32.3 \%)$ & $6(19.4 \%)$ \\
SDF & $19(51.4 \%)$ & $18(48.6 \%)$ & $24(64.9 \%)$ & $9(24.3 \%)$ & $4(8.1 \%)$ & $23(62.2 \%)$ & $12(32.4 \%)$ & $2(5.4 \%)$ \\
Total & $32(58.2 \%)$ & $23(41.8 \%)$ & $35(63.6 \%)$ & $15(27.3 \%)$ & $5(7.3 \%)$ & $32(58.2 \%)$ & $17(30.9 \%)$ & $6(10.9 \%)$ \\
\hline
\end{tabular}

species; no radicant species were found. In cerradão $17(54.8 \%)$ were apically twining, $11(35.5 \%)$ were tendrilling, and three $(9.7 \%)$ were scandent, while SDF included $24(64.9 \%)$ apically twining species, nine $(24.3 \%)$ tendrilling, and four $(10.8 \%)$ scandent (Table 2, Fig. 2).

Dispersal syndromes: Anemochory occurred in $32(58.2 \%)$ species overall, followed by autochory in 17 species (30.9\%), and zoochory in six species (10.9\%). In cerradão alone, anemochory occurred in 15 species $(48.4 \%)$, autochory in ten $(32.3 \%)$, and zoochory in six $(19.3 \%)$. The SDF included $23(62.2 \%)$ anemochorous species, 12 (32.4 $\%)$ autochorous, and two (5.4\%) zoochorous (Table 2, Fig. 2).

\section{DISCUSSION}

In cerradão and Seasonal Deciduous Forest of the Serra de Maracaju, the most species rich climber family was Dioscoreaceae, followed by Sapindaceae, Fabaceae, and Malpighiaceae. The latter three families are recognized as significant climber-rich families of the neotropics (Gentry, 1991) and dominants of seasonal forests (Hora \& Soares, 2002; Udulutsch, Assis, \& Picchi, 2004; Alcalá, Franceschi, \& Stranghetti, 2006). Fabaceae was especially species-rich in Cerrado of central Brazil (Mendonça et al., 1998; Rezende \& Ranga, 2005). In Serra de Maracaju, Fabaceae included six of 37 genera, and eight of 55 species of climbers, while Serjania (Sapindaceae), Heteropterys (Malpighiaceae), and Ipomoea (Convolvulaceae) were represented by five or six species each. This pattern is common in climber floras: a few genera include a large proportion of the species (Gentry, 1991). Dioscorea, with ten species, placed Dioscoreaceae as the richest family of the two vegetation types. This represents the first record of high species richness in Dioscoreaceae among climber floras in Brazil. Dioscorea includes over 325 species worldwide with highest diversity in seasonally wet forests (Gentry, 1991; Caddick, Wilkin, Rudal, Hedderson, \& Chase, 2002). Our high diversity of Dioscoreaceae, in comparison to other floras, may be due to include all flowering climber individuals, not just those exceeding the diameter of $1 \mathrm{~cm}$.

The two forest types differed by $70 \%$ in their climbing species, demonstrating floristic heterogeneity in the Serra de Maracaju. This pattern was noted for tree and shrub species of the area (Assunção et al., 2014). The shared climbing species $(30 \%)$ suggest that forest fragments of the broad Cerrado phytophysiognomy may function as corridors for generalist species (Pereira, Venturoli, \& Carvalho, 2011), in our case Smilax fluminensis, Manettia cordifolia, Mascagnia cordifolia, and Urvillea laevis, which are found in several vegetation types of Central Brazil (Udulutsch et al., 2004; Santos et al., 2009; Vargas et al., 2013). Cerrado in Brazil is often represented by small, natural or semi-natural fragments, which may serve as corridors that promote gene flow (Scariot \& Seville, 2005; Silva-Pereira, Venturoli, \& Carvalho, 2011).

Cerradão and Seasonal Deciduous Forest plots in our study included more herbaceous than woody climbing species, differing 
from most tropical forests previously reported (Udulutsch et al., 2004; Romaniuc-Neto, Godoi, Villagra, Almeida-Scabbia, \& Melo, 2012; Vargas et al., 2013). Families represented by numerous herbaceous climbers were Fabaceae, Dioscoreaceae, and Convolvulaceae, whereas families including woody species such as Bignoniaceae, Passifloraceae, and Vitaceae (Gentry, 1991) were less rich. Even within families otherwise known for woody species (e.g., Passifloraceae, Convolvulaceae), the species at the Serra de Maracaju were mostly herbaceous. Compared to SDF, cerradão has widely-spaced trees and shrubs, and an abundant herbaceous understory, consistent with high light availability (Gentry, 1991; Engel et al., 1998). In both cerradão and SDF, the trees and shrubs were small to medium sized and easily climbed by herbaceous species, compared to tall rainforest hosts, where woody climbers predominate (Balfour \& Bond, 1993; Burnham, 2004; Homeier, Englert, Leuchner, Weigelt, \& Unger, 2010). While abundant herbaceous climber species were noted in our study, they are rarely censured in other forests, thus our results await comparisons with other species-level censuses of stems of all sizes.

Apically twining species are dominant in other climber communities over species with alternative mechanisms, suggesting that it is an easier evolutionary route to climbing, it is more common among all climbing species, or it is a more efficient mechanism for climbing. Apical twining is the most common climbing mechanism in vegetation types from evergreen to dry forest (Gentry, 1991), and in Brazil it is prevalent in cerradão, seasonal forest, and riparian forests (Santos et al., 2009; Vargas et al., 2013). Apically twining climbers do not require specialized structures to climb successfully and have evolved in several families (Hergarty \& Caballé, 1991), including those with the largest number of species here: Dioscoreaceae, Fabaceae, Malpighiaceae, and Convolvulaceae. Tendrilling was the second-most prevalent climbing mechanism we found, and in cerradão was almost equivalent in frequency to apical twining. The difference in climbing mechanism observed between the two vegetation types may be a phylogenetic effect of the predominant families for each vegetation type. For example, seven tendrillate species of Bignoniaceae, Passifloraceae, Smilacaceae, and Vitaceae were found in cerradão, whereas only two species from these families were found in SDF. Conversely, the predominantly tendrillate family Sapindaceae included seven species in SDF and only four in cerradão. The Sapindaceae pattern, conformed to expectations, given the larger number of species in SDF.

Anemochory comprised the largest number of climbing species in both vegetation types, paralleling the predominant dispersal mode for climbers in dry forests of other tropical areas (Gentry, 1982; Wikander, 1984; Mantovani \& Martins, 1988; Solórzano, Ibarra-Manríquez, \& Oyama, 2002). Climber dispersal syndromes were not significantly different between the two forest types; however SDF, with a strongly synchronous leaf fall and higher canopy, did have more anemochory than did cerradão. Gentry (1991) reported a higher proportion of anemochorous climbing plant species than for trees and shrubs, a pattern confirmed here in both forest types (Assunção et al., 2014). Once climbers reach the canopy, branches of the emergent trees may facilitate dispersal of climbers with aerodynamic seeds or fruits. In addition, synchronous leaf fall and strong winds during periods of decreased precipitation, should allow seed and fruit dehydration, facilitating anemochory (Gentry, 1991; Gallagher, 2015; Schnitzer, Putz, Bongers, \& Kroening, 2015). However, phylogenetic history can have an important influence over character traits and may explain why trees differ from climbers in this characteristic. Among climbers of the Serra de Maracaju, just three families included the majority of anemochorous diaspores: Dioscoreaceae (ten species), Malpighiaceae (eight), and Sapindaceae (eight): over $80 \%$ of all anemochorous species observed.

The three most common character states among climber species in the two vegetation types were herbaceous life form, apical twining, and wind dispersal. These three traits 
are nearly universal in the species-rich Dioscoreaceae. Only two species in that family differ, and these were scored here as woody because of their relatively inflexible stems. These phylogenetically-correlated trait combinations in a flora comprised of just 55 species, can only be the basis for adaptive scenarios if the same traits are more variable in other members of the family that are subject to different environmental circumstances.

Cerradão and Seasonal Deciduous Forest show high species richness in Sapindaceae, Fabaceae, and Malpighiaceae, all recognized as families with high climber diversity elsewhere in the Neotropics. To these three families is added the largely herbaceous Dioscoreaceae, a new addition to botanically dominant climbing families of Brazilian forests. Although the two vegetation types are adjacent, they showed floristic differences, with a large proportion of their respective floras unknown in the other vegetation type. A minority of species may use seasonal forests as corridors between larger biogeographic areas, however more species are restricted to one or the other vegetation type. The morphological characteristics we evaluated probably showed no significant difference for ecological and evolutionary reasons because: 1) the two phytophysiognomies are found in the same climatic conditions, and 2) the small number of dominant families limited the suite of possible characteristics. Variations between the two climber floras in life form may be due to tree canopy height, and in climbing mechanism may be related to support plant girth, and in dispersal mode may be related to foliar deciduousness in host trees.

\section{ACKNOWLEDGMENTS}

The first author thanks the Coordenação de Aperfeiçoamento de Pessoal de Nivel Superior (CAPES) and the third author thanks the Fundação de Apoio ao Desenvolvimento do Ensino, Ciência e Tecnologia do Estado de Mato Grosso do Sul (FUNDECT) for granted fellowships, as well as colleagues and friends who assisted field collection. We thank the Pró-Reitoria de Pesquisa e PósGraduação (PROPP), Universidade Federal de Mato Grosso do Sul (UFMS) and the Post-Gradutate Program in Vegetal Biology (UFMS) for logistical support. We thank Vali J. Pott, Arnildo Pott, Maria Ana Farinaccio, Augusto Francener Nogueira Gonzaga, and Diogo Amorim de Araújo for helping with the species identification.

\section{RESUMEN}

La Serra de Maracaju yuxtapone los distintos tipos de vegetación de la floresta seca estacional y del cerradón (la fitofisiognomía del cerrado). Los dos tipos de vegetación son distintos en altura de copa, densidad de árboles y composición del sotobosque. Estas diferencias deben reflejarse en la composición de especies de plantas trepadoras que se encuentran en los dos tipos de bosque. Especies trepadoras de dos fragmentos forestales de la Serra de Maracaju han sido comparadas para responder: (1) ¿La riqueza de especies y composición florística de trepadoras es similar en el cerradón y en la floresta estacional decidua? (2) ¿Cuáles especies distinguen los dos tipos vegetacionales de otros? (3) ¿Los dos tipos vegetacionales difieren significativamente en mecanismo de ascensión, formas de vida y síndrome de dispersión en las especies trepadoras? Cuatro parcelas por tipo de floresta han sido muestreadas durante 24 meses. Las especies fueron identificadas y caracterizadas en tres rasgos discretos. Las diferencias proporcionales fueron analizadas usando el test chi-cuadrado. La riqueza y composición florística de trepadoras no fue similar en las dos formaciones: 37 especies en el cerradón y 31 en la floresta estacional decidua, con 13 especies compartidas. Dioscoreaceae, Fabaceae, Malpighiaceae y Sapindaceae corresponden al $60 \%$ de las especies trepadoras. Las formaciones poseen características comunes como la forma de vida herbácea, el mecanismo de ascensión voluble y la anemocoria. La familia predominante fue Dioscoreaceae, no prevalente en estudios en Brasil. A pesar de la proximidad geográfica, la composición florística de los fragmentos de cerradón y de la floresta estacional decidua difiere substancialmente. Las características morfológicas de las especies no difieren estadísticamente, posiblemente por las condiciones climáticas uniformes y la fuerte similitud entre las composiciones florísticas de las familias.

Palabras clave: mecanismo de ascensión, dispersión, formas de vida, Cerradón, Dioscoreaceae.

\section{REFERENCES}

Alcalá, M., Franceschi, N. C. S., \& Stranghetti, V. (2006). Florística de trechos de matas ciliares do Ribeirão 
Borá e Ribeirão Cubatão, Potirendaba - SP. Revista do Instituto Florestal, 18, 79-93.

APG III. (2009). An update of the Angiosperm Phylogeny Group classification for the orders and families of flowering plants: APG III. Botanical Journal of Linnean Society, 161, 105-121.

Araújo, D., \& Alves, M. (2010). Climbing plants of a fragmented area of lowland Atlantic Forest, Igarassu, Pernambuco (northeastern Brazil). Phytotaxa, 8, 1-24.

Assunção, V. A., Casagrande, J. C., \& Sartori, A. L. B. (2014). Floristics and reproductive phenology of trees and bushes in Central West Brazil. Anais da Academia Brasileira de Ciências, 86, 785-799.

Balfour, D. A., \& Bond, W. J. (1993). Factors limiting climber distribution and abundance in a southern African forest. Journal of Ecology, 81, 93-99.

Burnham, R. J. (2004). Alpha and beta diversity of lianas in Yasuní, Ecuador. Forest Ecology and Management, 190, 43-55.

Caddick, L. R., Wilkin, P., Rudal, P. J., Hedderson, T. A. J., \& Chase, M. W. (2002). Yams reclassified: A recircumscription of Dioscoreaceae and Dioscoreales. Taxon, 51, 103-114.

Clarke, K. R. (1993). Non-parametric multivariate analysis of changes in community structure. Australian Journal of Ecology, 18, 117-143.

Engel, V. L., Fonseca, R. C. B., \& Oliveira, R. D. (1998) Ecologia de lianas e o manejo de fragmentos florestais. Série técnica IPEF, 12, 43-64.

Filgueiras, T. S. (2002). Herbaceous plant communities. The Cerrados of Brazil: ecology and natural history of a neotropical savanna. In P. S. Oliveira, \& R. J. Marquis (Eds.), The Cerrados of Brazil: Ecology and natural history of a neotropical savanna (pp. 121139). New York: Columbia University Press.

Gallagher, R. V. (2015). Climbing plant diversity in Australia: taxonomy, biogeography, and functional traits. In S. A. Schnitzer, F. Bongers, R. J. Burnham, F. E. Putz (Eds.), Ecology of Lianas (pp.104-115). Chichester: John Wiley \& Sons Ltd.

Gentry, A. H. (1982). Neotropical floristic diversity: phytogeographical connections between Central and South America, Pleistocene climatic fluctuations, or an accident of the Andean orogeny? Annals of Missouri Botanical Garden, 69, 557-593.

Gentry, A. H. (1991). The distribution and evolution of climbing plants. In F. E. Putz, \& H. A. Mooney (Eds.), The Biology of Vines (pp. 3-41). Cambridge: Cambridge University Press.

Hergarty, E. E., \& Caballé, G. (1991). Distribution and abundance of vines in forest communities. In F. E.
Putz \& H. A. Mooney (Eds.), The Biology of Vines (pp. 313-335). Cambridge: Cambridge University Press.

Homeier, J., Englert, F., Leuchner, C., Weigelt, P., \& Unger, M. (2010). Factors controlling the abundance of lianas along an altitudinal transect of tropical forests in Ecuador. Forest Ecology and Management, 259, 1399-1405.

Hora, R. C. \& Soares, J. J. (2002). Estrutura fitossociológica da comunidade de lianas em uma floresta estacional semidecidual na Fazenda Canchim, São Carlos, SP. Revista Brasileira de Botânica, 25, 323-329.

Instituto Brasileiro de Geografia e Estatística (IBGE). (2012). Manual Técnico da Vegetação Brasileira. Rio de Janeiro, RJ: Fundação Instituto Brasileiro de Geografia e Estatística.

Köeppen, W. (1948). Climatologia, con un Estudio de los Climas de la Tierra. México, M.X.: Fondo de Cultura Económica.

Mantovani, W., \& Martins, F. R. (1988). Variações fenológicas das espécies do cerrado da Reserva Biológica de Moji Guaçu, Estado de São Paulo. Revista Brasileira de Botânica, 11, 101-102.

Martins, G. R. (2003). Arqueologia do Planalto MaracajuCampo Grande. Brasília: Ministério da Integração Nacional. Campo Grande: UFMS.

Mendonça, R. C., Felfili, J. M., Walter, B. M. T., SilvaJúnior, M. C., Rezende, A. V., Filgueiras, T. S., \& Nogueira, P. E. N. (1998). Flora vascular do Cerrado. In M. S. Sano \& S. P. Almeida (Eds.), Cerrado: ambiente e flora (pp. 287-556). Planaltina, DF: Embrapa - Cerrados.

Ministério do Meio Ambiente (MMA). (2007). Áreas Prioritárias para Conservação, Uso Sustentável e Repartição de Beneficios da Biodiversidade Brasileira: Atualização - Portaria $M M A n^{\circ} 9$, de 23 de janeiro de 2007. Brasília, BR: Ministério do Meio Ambiente, Secretaria de Biodiversidade e Florestas.

Oliveira-Filho, A. T., \& Ratter, J. A. (2002). Vegetation physiognomies and woody flora of the cerrado biome. In P. S. Oliveira, \& R. J. Marquis (Eds.), The Cerrados of Brazil: Ecology and Natural History of a Neotropical Savanna (pp-91-120). New York, NY: Columbia University Press.

Pereira, B. A. S., Venturoli, F., \& Carvalho, F. A. (2011) Florestas estacionais no Cerrado: uma visão geral. Pesquisa Agropecuária Tropical, 41, 446-455.

Pinheiro, M. H. O., \& Monteiro, R. (2010). Contribution to the discussions on the origin of the cerrado biome: Brazilian savanna. Brazilian Journal of Biology, $70,95-102$

Putz, F. E., \& Holbrook, M. (1991). Biomechanical studies of vines. In F. E. Putz, \& H. A. Mooney (Eds.), 
The Biology of Vines (pp.73-97). Cambridge: Cambridge University Press.

Putz, F. E. (1984). The natural history of lianas on Barro Colorado Island, Panama. Ecology, 65, 1713-1724.

RADAMBRASIL. (1982). Projeto RADAMBRASIL. Levantamento de recursos naturais. Folha SF 21, Campo Grande: geologia, geomorfologia, pedologia, vegetação e uso potencial da terra. Rio de Janeiro, RJ: Ministério de Minas e Energia.

Ramos, W. M., \& Sartori, A. L. B. (2013). Floristic analysis and dispersal syndromes of woody species of the Serra de Maracaju, Mato Grosso do Sul, Brazil. Brazilian Journal of Biology, 73, 67-78.

Rezende, A. A., \& Ranga, N. T. (2005). Lianas da Estação Ecológica do Noroeste Paulista, São José do Rio Preto/Mirassol, SP, Brasil. Acta Botanica Brasilica, 19, 273-279.

Ribeiro, J. F., \& Walter, B. M. (1998). Fitofisionomias do bioma cerrado. In S. M. Sano \& S. P. Almeida (Eds.), Cerrado: ambiente e flora (pp. 89-166). Planaltina, DF: Embrapa - Cerrados.

Richards, P. W. (1952). The tropical rain forest: an ecological study. Cambridge, MA: Cambridge University Press.

Romaniuc-Neto, S., Godoi, J. V., Villagra, B. L. P., Almeida-Scabbia, R. J. D., \& Melo, M. M. D. R. F. (2012). Floristic, phytosociological and phenology of climbers riparian of "Fazenda Campininha", Mogi Guaçu, São Paulo State, Brazil. Hoehnea, 39, 145-155.

Salis, S. M., Silva, M. P. D., Mattos, P. P. D., Silva, J. S. V., Pott, V. J., \& Pott, A. (2004). Fitossociologia de remanescentes de floresta estacional decidual em Corumbá, Estado do Mato Grosso do Sul, Brasil. Revista Brasileira de Botânica, 27, 671-684.

Santos, K. D., Kinoshita, L. S., \& Rezende, A. A. (2009). Species composition of climbers in seasonal semideciduous forest fragments of Southeastern Brazil. Biota Neotropica, 9, 175-188.
Scariot, A., \& Sevilha, A. C. (2005). Biodiversidade, Estrutura e Conservação de Florestas Estacionais Deciduais no Cerrado. In A. Scariot, J. M. Felfili, \& J. C. Sousa-Silva (Eds.), Cerrado: Ecologia, Biodiversidade e Conservação (pp.123-139). Brasília, DF: Ministério do Meio Ambiente.

Schenck, H. (1892). Beitrage zur Biologie und Anatomie der Lianen, im Besonderen der in Brasilien einheimischen Arten. 1. Beiträge zur Biologie der Lianen. In A. F. W Schimper (Ed.), Botanische Mittheilungen aus den Tropen 5 (pp. 1-253). Jena, TH: botanische Mittheilungen aus den Tropen.

Schnitzer, S. A., Putz, F. E., Bongers, F., \& Kroening, K. (2015). The past, present, and potential future of liana ecology. In S. A. Schnitzer, F. Bongers, R. J. Burnham, \& F. E. Putz (Eds.), Ecology of Lianas (pp. 3-10). Chichester, U. K.: John Wiley \& Sons Ltd.

Silva-Pereira, B. A., Venturoli, F., \& Carvalho, F. A. (2011). Florestas estacionais no cerrado: uma visão geral. Pesquisa Agropecuária Tropical, 41, 446-455.

Solórzano, S., Ibarra-Manríquez, G., \& Oyama, K. (2002). Liana diversity and reproductive attributes in two tropical forests in Mexico. Biodiversity and Conservation, 11, 197-212.

Udulutsch, R. G., Assis, M. A., \& Picchi, D. G. (2004). Florística de trepadeiras numa floresta estacional semidecídua, Rio Claro-Araras, estado de São Paulo, Brasil. Revista Brasileira de Botânica, 27, 125-134.

Van der Pijl, L. (1982). Principles of Dispersal in Higher Plants. Berlin, B.E.: Springer-Verlag.

Vargas, B. C., Araújo, G. M., Schiavini, I. S., Rosa, P. O., \& Hattori,. E. K. O. (2013). Florística de trepadeiras em floresta semidecidual e em mata ciliar no Vale do Rio Araguari, MG. Bioscience Journal, 29, 185-197.

Wikander, T. (1984). Mecanismos de dispersión de diásporas de una selva decidua en Venezuela. Biotropica, $16,276-283$.

Zar, J. H. (1984). Biostatistical Analysis (2 Ed.). New Jersey, U. S.: Prentice Hall. 